\title{
Covid-19 ve Nörolojik Bozukluklar
}

\section{Covid-19 and Neurological Disorders}

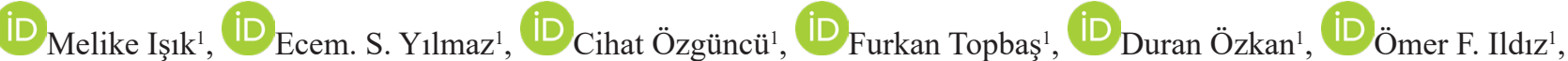
iD Sevde Tekneci ${ }^{1}$ (iD Ayşenur Ersoy ${ }^{1}$, iD M. Seda Özaltın², iD ${ }_{\text {Buket Kuruçay }}^{2}$, iD Şerefnur Öztürk ${ }^{1}$

${ }^{1}$ Selçuk Üniversitesi Tıp Fakültesi, Nöroloji AD.

${ }^{2}$ Selçuk Üniversitesi Tıp Fakültesi, Ruh Sağlığı ve Hastalıkları AD.

$\ddot{\mathrm{O} z}$

Dünya Sağlık Örgütü tarafindan 11 Mart 2019'da pandemi olarak kabul edilen COVID-19 hastalığının pandeminin ilk döneminde öncelikle solunum yollarını etkileyen ve ciddi akut solunum yetmezliğine (SARS) neden olan bir viral enfeksiyon olduğu kabul edilmiştir. Zaman içinde vasküler sistemler başta olmak üzere diğer organ sistemlerini ve en önemlisi de diğer sistemlerle beraber nörolojik sistemleri ve hatta bazen sadece nörolojik sistemleri etkilediği ortaya konmuştur.

Ciddi semptomu olmayan hastalarda bile koku alma kaybı sık olarak görülmekte olup bazı hastalarda ilk veya tek belirti olabilmektedir. Viral enfeksiyonun iyileşmesine rağmen koku alma fonksiyonunun aynı hızla kazanılamaması yaşam kalitesini etkileyen önemli bir nörolojik tutulumdur.

Dünyada pandemi sürecinde vaka bildirimleri ve klinik verilerin analizleri ile hızlı bilgi akışı devam etmektedir. Bu yazıda literatür incelemesi ile dünyada bildirilen nörolojik tutulumlar ışı̆̆ında kranial sinir tutulumları, serebrovasküler hastalıklar ve inme, ansefalit, epilepsi, Guillain Barré sendromu, psikiyatrik bozukluklar ile ilgili güncel bilgilerin paylaşılması amaçlanmıştır.

Anahtar Kelimeler: COVID-19, Pandemi, Nöroloji, Serebrovasküler Hastalıklar, Epilepsi, Koku, kranial sinirler

\section{Abstract}

COVID-19 disease was accepted as a pandemic by the World Health Organization in 11 March 2019 . At the earlier period of the pandemic, it was first recognized as a viral infection that affects the respiratory tract and causes severe acute respiratory failure (SARS). Over time, it has been demonstrated that it affects other organ systems, primarily vascular systems, and most importantly, neurological systems together with other systems, and sometimes even only neurological systems.

Loss of smell is common even in patients without serious symptoms, and may be the first or only symptom in some patients. Failure to regain the olfactory function as rapidly despite the recovery of viral infection is an important neurological involvement affecting the quality of life.

During the pandemic process in the world, fast information flow continues with case reports and analysis of clinical data. In this article, it is aimed to share current information about cranial nerve involvement, cerebrovascular diseases and stroke, encephalitis, epilepsy, Guillain Barré syndrome, and psychiatric disorders in the light of neurological involvement reported in the world with a literature review.

Keywords: COVID-19, Pandemic, Neurology, Cerebrovascular diseases, Epilepsy olfactor, cranial nerves

Yazışma Adresi: Ecem S. Yılmaz, Selçuk Üniversitesi Tıp Fakültesi Nöroloji AD. Selçuklu-Konya 42250

E-Posta: secemyilmaz@hotmail.com

Alınma Tarihi: 08.10.2020 / Kabul Tarihi: 12.08.2021 / Yayımlanma Tarihi: 20.09.2021

Covid-19 ve Nöroloji - Işıłk ve ark. 


\section{Giriş}

Nörolojik hastalıklar bütün dünyada sağlıkta global kaybı en yaygın ve sağlıklı yıl kaybında da birinci sırada yer alan hastalık grubunu oluşturmaktadır. Her y1l DALY kaybının \%11,6's1 nörolojik hastalıklar nedeniyle olmakta ve 9,4 milyon kişi hayatını nörolojik hastalıklar nedeniyle kaybetmektedir (1-2).

COVID-19 pandemisi ile zaten oldukça yüklü olan nörolojik hastalık yükü yeni bir tehditle karşı karşıya kalmıştır. Nörolojik hastalıklara neden olan çok sayıda değiştirilemeyen ve değiştirilebilen risk faktörleri bütün dünyada hızla artmakta iken, son aylarda bütün dünyada ciddi sağllk problem durumunda olan ve Dünya Sağlık Örgütü tarafindan 11 Mart 2020 tarihi itibariyle pandemi olarak kabul edilen COVID-19 hastalığı ile ilgili olarak başlangıç ve devam sürecinde bildirilen raporlar, SARS CoV-2 virüsünün, daha önce hastalık etkeni olan corona virüslerden daha da potent olarak, sadece solunum yollarını etkileyerek ciddi akut solunum yetmezliğine (SARS) neden olmadığını özellikle vasküler sistemler başta olmak üzere diğer organ sistemlerini ve en önemlisi de diğer sistemlerle beraber nörolojik sistemleri ve hatta bazen sadece nörolojik sistemleri de etkilediğini ortaya koymaktadır (3-10). Hastalığın tanısında özellikle solunum sistemine yönelik tetkikler yapılmakta ve direkt AC grafisi ve toraks tomografisi tanıda en önemli araçları oluşturmaktadır. Hastalık en sık tutulumun yaşandığı göğüs hastalıkları alanında değil, neden olduğu farklı tutulumlar dolayısı ile başta nöroloji olmak üzere diğer branşlarca da yakından izlenmekedir. Tanı sürecindeki yoğunluk hastaların kranial incelemelerine genellikle izin vermemekte ve bu hastalar nörolojik tutuluma sahip olsalar bile bu durum ortaya konulamamaktadır. Hastların nörolojik tutulumlarının gösterildiği kranial görüntülemelere ilişkin raporlar ise giderek artmaktadır (11). Yine aynı şekilde bu hastalarda beyin omurilik sıvı incelemeleri de genellikle yapılamamakta bu da hastalığın ansefalit ve menengial tutulumunun tespitini zorlaştırmaktadır. Biz bu çalışma ile COVID-19 hastalığında virüsün etki mekanizmalarını nörolojik belirtilerini daha iyi anlamak, pandemiden etkilenen hastaların multidisiplier yaklaşımla değerlendirilmesine katkı sunabilmek için bu derlemeyi hazırladik.

\section{COVID-19 Epidemiyolojisi}

Coronavirüs $(\mathrm{CoV})$ başlica insan solunum sistemini hedef alan zarfl bir RNA virüsüdür. Son 20 yılda ağır akut solunum yolu yetersizliği sendromu (SARS) ve Orta Doğu Solunum sendromu (MERS) olmak üzere iki büyük ölçekli pandemiye neden olduğu bilinen coronavirüsün yeni tipi, Aralık 2019'da Çin'in Wuhan eyaletinde ortaya çıkmıştır (12). Pnomoni yanısıra çoklu organ tutulumu ile ciddi klinik tablolar yaratan, SARS-CoV-2 virüsü tarafından oluşturulan bu hastalık, ortaya çıktığı yılın adıyla anılarak Şubat 2020'de Dünya Sağlık Örgütü (WHO) tarafından COVID-19 olarak adlandırılmıştır (13).

Yeni CoV'nin anjiyotensin dönüştürücü enzim-2 (ACE2) reseptörü üzerinden etki ettiği ve bu özelliği ile SARS-CoV'a benzer semptomlara neden olduğu gösterilmiştir $(12,14)$.

2012 yılında ilk vakanın Suudi Arabistan'da tespit edildiği, 2947 kişiyi enfekte edip 858 kişinin ölüme neden olan MERSCoV (Ortadoğu Respiratuar Sendromu Corona Virüs) ile 50\% genomik benzerlik saptanmıştır. Genom sekansı olarak yarasa CoV RaTG13'e \%96,2 oranında benzerlik göstermektedir. Yapılan filogenetik çalışmalarda diğer potansiyel ara konakçı hayvanlardan da sözedilmektedir (kaplumbağa, yılan, penguen gibi). Yapılan çalışmalar ve filiyasyon gözlemleri SAR-CoV-2'nin insandan insana yayllımının temel olarak hastalığın inkubasyon ve hastalık dönemini yaşayan aile bireyleri ve akraba temasları ile oluştuğunu göstermektedir. Hastalık özelliklerinin iyi bilinmesi daha doğru epidemiyolojik verilere ulaşılmasını sağlayacaktır (15-18).

Temmuz baş1 -2020 itibariyle bütün dünyada 10 milyondan fazla kişi SARS-CoV-2 ile enfekte durumdadır ve bu sayı halen giderek kaygı verici şekilde artmaktadır. Ağustos başında ise konfirme COVID -19 vakaları 17889134'e ve kaybedilen hasta sayısı 686145'e ulaşmıştır (19).

Şu ana kadar dünyada 32.029.000 toplam vaka, 231.300 yeni vaka, 979.212 ölüm yaşandığı bildirilmektedir ve pandemi seyri kaygı verici durumunu sürdürmektedir (20).

Hastalığın bulaş yollarını engellemeye çalışırken, virüsün asemptomatik, presemptomatik ve semptomatik taşıyıcılarının mevcut olması kontrolü zorlaştıran durumlardan biri olmaktadır. SARS-CoV-2 tespiti için tanıda kullanılan ters transcription polimeraz zincir reaksiyonu testi (PCR) test zamanı ve kalitesine bağlı olarak, hastaların \%20-67'sinde yanlış negatif sonuçlanabilir. COVID-19 hastalığ sepsis veya akut solunum yetmezliğine kadar değişebilir. Hastaların $\% 20$ 'si hospitalize edilmekte ve bunların da \%5'i ciddi semptomları nedeniyle yoğun bakıma ihtiyaç duymaktadır (21). COVID-19'un erken transmisyon dinamikleri incelendiğinde ortalama inkubasyon periyodunun 5,2 gün (12,5 güne kadar uazyabilir) olduğu bildirilmiştir. Ortalama inkubasyon süresinin 6,4 gün olarak bildiren çalışmalar yanısıra 19 güne kadar uzayan sıradışı vakalar da bilinmektedir. Bu nedenle 14 gün karantina süresi önerilmektedir (22).

\section{COVID 19 ve Nörolojik Tutulum}

Coronavirüslerin başlıca hedefi solunum sistemi olmakla birlikte, artan kanıtlar bu virüslerin nöroinvazyon ve nörotropizm yeteneği ile merkezi sinir sistemini de etkilediğini ortaya koymaktadır. COVID-19 hastalarının baş ağrısı, bulantı, kusma, kas ağrısı, baş dönmesi, hipozmi ve bilinç bozukluğu gibi nonspesifik nörolojik tutulum düşündüren semptomlar gösterdiği bildirilmiş; ensefalit, demiyelinizasyon, epilepsi, nöropati ve inme de COVID-19 ile ilişkilendirilmiştir. Hatta COVID-19 hastalarında gelişen refrakter solunum yetmezliğinde, medüller kardiyovasküler merkezin virüs ile invazyonunun katkıda bulunabileceği gündeme gelmiştir. Corona virüslerin BOS ve beyin parankiminde de bulunduğu bildirilmiştir. Nörolojik bulguların genel olarak \%36.4 olarak ortaya çıktğını ilk raporlar ortaya koymuştur. Nörolojik belirtilerin daha ciddi enfeksiyonu olan hastalarda daha s1k görüldüğü izlenmiştir. Bu durumdaki hastalarda akut serebrovasküler hastalık \%5,7, bilinç bozukluğu \%14, miyopatik hasar ise \%19,3 oranında bildirilmiştir Hareket bozuklukları ve myoklonus da bildirilen nörolojik bozukluklardandır (23-28).

Bu semptomlar zaman zaman ciddi nörolojik morbidite ve mortaliteye sebep olabilmektedir (29). Türkiye'den Karadas ve ark. nın yapmış oldukları çalışmada 239 COVID -19 enfeksiyonlu hastada nörolojik bulgular \%34.7 oranında bildirilmiştir. En yaygın nörolojik semptom başağrısı olarak tespit edilmiştir $(\% 27,6)$. Ayrıca kreatin kinaz düzeyleri de nörolojik bulgusu olan ve kas ağrısı olan hastalarda 
yüksek bulunmuştur (30).

COVID-19 ve nörolojik sistem tutulumu ile ilgili raporlar giderek fark $l_{1}$ sistemlerdeki tutulumları da ortaya koymaktadır. Post enfeksiyöz akut transvers miyelitli olgu, spinal kord nöronlarının plazma membranında ekprese edilen ACE-2 reseptörleri aracılığ ile spinal kordun da SARSCoV-2 için hedef olabildiğini düşündürmektedir. Nöroinvazyon yoluyla direkt hasar yanısıra immunsistemin aşırı aktivasyonu ile indirekt hasarın da hastalıkta rol oynadığı bildirilmektedir. Radyolojik bulgusu olmayan akut başlangıçlı geçici tetraparetik durumların da virüsün nöroirritatif nörobaskılayıcı etkisine bağlı olabileceği ileri sürülmüştür (31-33).

\section{COVID 19 Enfeksiyonu ve Diğer Yaygın Nörolojik Hastalıkların Birlikteliği}

\section{Kranial Sinir Tutulumları}

COVID-19 enfeksiyonu sırasında oldukça sık olarak kranial sinir tutulumları da bildirilmektedir. Kranial sinir tutulumu içinde en s1k olfaktör sinir tutulumu bildirilmektedir. Mevcut kanitlar olfaktör disfonksiyonun COVID-19'da oldukça yaygın olduğunu göstermektedir. COVID-19 hastalarının \% 25 'ine kadarı ilk semptom olarak ani başlayan koku alma bozukluğu (anozmi) yaşayabilir. Birkaç hafta içinde COVID-19 olfaktör disfoksiyon vakalarının büyük bir kısmı düzelebilir. Koku alma bozukluğu ani anozmi şeklinde olabileceği gibi, bazı hastalarda tek bulgu olarak da ortaya çıkabilir, altı hastanın birinde koku alma kaybı izole bir semptom olarak bildirilmektedir (34-35).

COVID-19 hastalığı seyrinde ortaya çıkan koku kaybı daha hafif bir klinik seyir ile ilişkili olabilir. Yaygın olarak kullanılan bir koku testi olan Pennsylvania Üniversitesi Koku Tanımlama Testi (UPSIT), 60 doğrulanmış COVID-19 hastalığı ile yatırılmış olan hastaya ve 60 yaş ve cinsiyet uyumlu kontrole koku alma işlev kaybının ölçüsünü ve sıklığını değerlendirmek için uygulanmıştır. Çalışmada 60 hastanın hastanın 53'ü (\% 98) bazı koku fonksiyon bozuklukları sergilemiştir (ortalama [\% 95 CI] UPSIT skoru: 20.98 [19.47, 22.48]; kontroller: 34.10 [33.31, 34.88]; p <0.0001). Altmış hastanın 38'i (\%58) ya anozmik (15/60;\% 25) ya da ciddi mikrozmik (20/60;\% 33); 16'sında orta mikrozmi $(16 / 60 ; \% 27), 8$ hafif mikrozmi $(8 / 60 ; \% 13)$ ve 1 normozmi (1/60;\% 2) göstermiştir (36).

Koku kaybına neden olan mekanizma araştırılmaktadır. COVID-19 ve enfekte olmamış kontroller ve doğrulanmış hastalardan alınan olfaktör epitelyum biyopsileri incelenmiştir. Enflamatuvar belirteçlerden Tümör nekroz faktörü $\alpha$ (TNF-a) ve interlökin-1-beta (IL-1B) düzeyleri ELISA kullanılarak değerlendirilmiş ve gruplar arasında karşılaştırılmıştır. Gruplar arasında IL-1 $\beta$ 'da hiçbir fark görülmemiştir. COVID-19'lu hastalarda koku alma epitelinde TNF- $\alpha$ düzeylerinde artış gözlenmiştir. Bu durum, koku alma epitelyumunun doğrudan inflamasyonunun, COVID-19'lu birçok hastada tarif edilen akut koku kaybında rol oynayabileceğini düşündürmektedir. $\mathrm{Bu}$ virüslerin ayrıca trigeminal sinir gibi diğer kranial sinirlere de retrograd aksonal transportla taşınabileceği düşünülmektedir. Multipl kranial sinir tutulumu da kontrast madde tututlumu ile bildirilmiştir (37-38).

\section{Serebrovasküler hastalıklar ve inme}

COVID-19 enfeksiyonu ile inme riski arasındaki ilişki her gün artan olgu bildirimleri ile giderek daha iyi anlaşılmaktadır. Birçok ülkede hastane başvurularının ve COVID-19 enfeksiyonu dışında kalan hasta kabullerinin azalması nedeni ile inme hasta sayısının azalmış görünmesine rağmen COVID-19 enfeksiyonunun çeşitli mekanizmalarla inmeye neden olabileceği öne sürülmüştür (39).

Enfeksiyonla beraber hastalarda meydana gelen hiperkoagulabilitenin inmenin etyopatogenezinde rol aldığı düşünülmektedir. Yüksek D-dimer düzeyleri ve yüksek fibrinojen ile "sepsis kaynaklı koagulopati" (SIC) oluşabilmekte ve sonrasında yaygın damar içi pihtılaşma (DIC) gelişebilmektedir. Bu süreç de tromboza ve kanamaya yatkınlığı oluşturmaktadır. D-dimer yüksekliği mevcut olan hastalarda antikoagulan tedaviden fayda sağlanması da bu durumu desteklemektedir (40). Hiperkoagulasyona yol açtığı düşünülen mekanizmalar arasında; solunum sıkıntısına sekonder gelişen hipoksi ve hipoksi ile indüklenen transkripsiyon faktöre bağlı sinyal yolağının aktive olması ile ortaya çıkan viskozite artışı, pulmoner hiperinflamasyonla trombopoetin salınımının artması ve trombositoz meydana gelmesi, sitokin firtınası sonucu meydana gelen koagulasyon kaskadının aktive olması, özellikle HIV ve hepatit $\mathrm{C}$ ile beraber görüldüğü bilinen viral enfeksiyonlaras ekonder gelişen antifosfolipit antikor salınımı, virüsün bağlanması ile hücre içine geçen ACE2 enziminin destrüksiyonu ile gözlenen anjiotensin 2 artışının tromboza yatkınlık oluşturması ve endotel harabiyetine bağlı koagulasyon kaskadının aktivasyonu bulunmaktadır. SARS-CoV-2 virüsü beyinde endotelial hücerelerde ve düz kas hücrelerinde anjiotensin dönüştürücü enzim -2 (ACE-2) reseptörlerine bağlanmaktadır (41)

Diyabet ve hipertansiyon gibi komorbit hastalığ olan kişilerin enfeksiyona yakalanma oranlarının daha fazla olduğu bilinmektedir. $\mathrm{Bu}$ hasta gruplarının COVID -19 enfeksiyonuna yatkınlığının fazla olduğu kanıtlanmış olmamakla beraber COVID-19 ile enfekte olup durumu ciddi olan hastalarda diyabet ve hipertansiyon bulunma oran durumu hafif olan hastalardan daha fazla bulunmuştur. Bu hasta grubu aynı zamanda inme için de artmış risk altındadır. Bu nedenle komorbid hastalıklarla beraber meydana gelecek koagulopati inmeye de zemin hazırlamaktadır $(42,43)$. Covid -19 hastalı̆̆ 1 sırasında inme ortaya çıkmasında önemli bir etyolojik neden olarak da D-Dimer yüksekliği bilinmektedir. Yan X ve arkadaşları hastanede yatarak tedavi idilen 2377 hastanın \%76'sında D-dimer yüksekliği tespit edildiğini bildirmişlerdir. D-dimer seviyesi yüksek olan hastalar daha fazla yoğun bakım ihtiyacı ve daha fazla trombotik olaya maruz kalma eğilimi göstermiştir. Özellikle D-Dimer seviyesi $2000 \mathrm{ng} / \mathrm{ml}$ den yüksek olan hastalarda tromboz oranı $\% 37,8$ 'e yükselirken, ölüm olranı da \%47 olarak tespit edilmiştir (44).

İnme, COVID-19 salgınının ortasında bile olağan acil bakım gerektiren tıbbi bir acil durum olmaya devam etmektedir. COVID19'un toplumda yayılma derecesi ve asemptomatik bulaşma vakaları göz önüne alındığında, akut inme semptomları olan tüm hastalar şüpheli veya olası COVID-19 hastaları olarak tedavi edilmeli ve fiziksel olarak temas halindeki tüm personel uygun kişisel koruyucu ekipman kullanmalıdır. Tüm hastalar inme bakımı standardını almalı ve büyük damar tıkanıklığından şüphelenildiğinde trombolitik tedavi ve trombektomi açısından COVID 19 önlem ve düzenlemeleri ile tanı ve tedavi süreci gecikmeden yürütülmelidir (45).

\section{Ansefalit}

Ensefalitler viral, bakteriyel, fungal etyolojik ajanlar yanısıra otoimmün mekamizmalarla da ortaya çıkan ve özellikle mental durum değişikliği olmak üzere tutulum bölgesine göre değişik fokal 
belirtilerle ortaya çıkabilen santral sinir sisteminin enfeksiyöz ve inflamatuvar hastalığıdır ve otoimmün ciddi sonuçlara yol açabilen santral sinir sisteminin enfeksiyöz ve enflamatuar kökenli hastalığıdır (46). Ensefalitlerin kuzey Avrupa'da y1llik insidans1 2-3/100,000 olarak bildirilmiştir. Bu sayının \%40'1 enfeksiyöz sebepler, \%40’1 bilinmeyen sebepler iken yaklaşı \%20'sini immün aracılı ensefalitler oluşturur (47).

Hastalar genellikle değişken mental durum, baş ağrısı, yüksek ateş ve nöbet benzeri şikayetler ile başvururlar (48). Ensefalit etyolojileri farklı olduğu için hastanın kliniği de değişkenlik gösterebilir. Ayırıcı tanı yapmak ve tedaviye hızlı başlamak için oldukça önemlidir. Hastaların uygun yönetimi için ensefalitten şüphelendikten sonra yapılmas1 gereken önemli testler ise elektroensefalografi (EEG), Manyetik Rezonans Görüntüleme (MRG), lomber ponksiyon (LP) dir (46). Başta inme olmak üzere, diğer nörolojik hastalıkların COVID-19 nedeniyle arttığı bildirilse de ensefalit kliniği sadece vaka bazında veya az sayıda serilerden oluşmaktadır. COVID 19 hastalığını takiben transvers myelit de bildirilmiştir (49-55). Ansefalit tablosu olmasa da ansefalopati de sık bildirilen nörolojik bozukluklardandır $(6,56)$. COVID-19'un ensefalopati patofizyolojisi için birkaç hipotez ortaya atılmıştır. Virusun ilk giriş noktası olan burun ve olfaktor sinir üzerinden serebrospinal sıvı (BOS) ve beyne ulaşmış olabileceği öngörülmektedir. $\mathrm{Bu}$ şekilde nöronal yolak üzerinden taşınmış olabileceği düşünülmektedir (57).

SARS-CoV-2 nin ACE-2 reseptörüne bağlanma özelliği dolayıs1 ile beyinde endotelial reseptörlere bağlanması ansefalopati nedeni olabileceği gibi, virüsün kan-beyin bariyeri hasarı oluşturarak kapiler endotelden santral sinir sistemine giriş yapma olasıllı̆g 1 da bildirilmektedir.

Japonya'dan bildirilen ilk ansefalit vaka raporunda 24 yaşında erkek hastanın evde bilinçsiz halde bulunduğu ve hastaneye getirildiğinde nöbet geçirmeye başladığı, muayenesinde ise belirgin ense sertliği tespit edilmiştir. Hastanın nazofarenksten yapılan sürüntü örneği COVID-19 için negatif sonuçlanmış ve beyin MRG'de flair sekansta sağ mezialtemporal bölge ve hipokampuste ensefalitle uyumlu hiperintensite izlenmiştir. Lomber ponksiyon (LP) ile beyin omurilik sıvısında BOS'da COVID-19 PCR tetkiki pozitif sonuçlanmıştır. Hastanın kranial görüntülemesinde yaygın sinüzit olması nedeni ile retrograd sinaptik yolla virüsün taşındığı düşünülmektedir (58).

Türkiye'den bildirilen bir vakada ise 35 yaşında kadın hastanın, şiddetli baş ağrısı, bulant1, ilaca dirençli tekrarlayan nöbetle hastaneye başvurduğu, hastanın kranial MRG'da sol temporal lobda hiperintensite ve spektroskopide kolin piki ve $\mathrm{N}$-asetilaspartat düşüşü dikkat çektiği bildirilmiştir. Hasta yüksek gradeliglioma olarak değerlendirilmiş iken çoklu antiepileptik tedaviye dirençli olması sebebiyle sol temporal lobektomi uygulanmıştır. Bu sırada hastanın eşi COVID-19 tanısıyla hastaneye yatırılmış ve hastaya yapılan PCR testi de pozitif sonuçlanmıştır. Rezeke edilen kitle histopatolojisi ensefalit lehine sonuçlanmıştır ve bu durum COVID-19 enfeksiyonunun görüntülemelerde glial tümör benzeri bulgu verdiği ortaya koymuştur. Hastanın nöbetleri kontrol altına alınmış ve taburcu edilmiştir (59). Altmış beş yaştan genç olan fatal seyirli COVID 19 vakalarında yapılan otopsilerde yaygın lenfositik panasefalik menenjit bulguları tespit edilmiştir (60).

Yeni bir enfeksiyon kaynağı olması sebebiyle COVID-19 sistemik hastalı̆̆ında veya ensefalitinde kullanılabilecek kesin bir tedavi bulunmamakta fakat ensefalitlerin genelinde kullanılan beyin ödemini azaltıcı mannitol ve steroid gibi tedavilerin kullanılabileceği belirtilmektedir. Bununla birlikte nöbet profilaksisi için antiepileptik ilaçların tedaviye eklenmesi önerilmektedir (61). Ensefalit olması sebebiyle bazı vakalarda kullanılan seftriakson veya asiklovir tedavisinin COVID-19 ensefalitinde etkileri kanıtlanmamıștır. Kinolon türevleri, faviripavir gibi tedavilerin COVID-19'da faydalı olduğu ifade edilse bile aynı şekilde ensefalite yönelik etkisiyle ilgili kesin bir veri bulunmamaktadır (22).

Sonuç olarak, sadece ateş ve solunum problemi değil, nörolojik semptomları bulunan hastalarda da COVID-19'dan şüphelenilmesi, nöbet, bilinç kaybı gibi ensefalit benzeri bulgu geliştirmeleri halinde nazofarenks sürüntü testleri negatif olsa bile BOS'tan örnek gönderilmesi ve yoğun bakım ünitesine alınarak vital bulgularının ve semptomlarının yakın takibi gerekmektedir. Özellikle bu hastalar multidisipliner yaklaşıma ihtiyaç duymaktadır. Vaka raporlarında da bahsedildiği şekliyle uygun tedavi desteği ve erken tanı sayesinde yüz güldürücü sonuçlar alınabilmektedir.

\section{Epilepsi}

Literatürde COVID-19'lu hastalarda tekrarlayan geçici jeneralize tonik-klonik nöbet vakaları bildirilmiştir. Bildirilen olgularda epileptik nöbet öyküsü ve ailede nöbet bozukluğu öyküsü yoktur (62-64). İran'dan bildirilen bir olgu sunumunda; daha önce nöbet geçirmeyen veya aile öyküsü olmayan 30 yaşındaki kadın hasta yeni başlayan nöbetlerle başvurmuştur. Beyin manyetik MRI ve BOS incelemesi ve polimeraz zincir reaksiyonu (PCR) ile SARS-CoV-2 testi dahil CSF muayenesi normal olmasına rağmen, enfeksiyonla ilişkilendirilerek, COVID-19, epileptik nöbetlerinin etiyolojisi olarak bildirilmiştir (63).

Enflamatuar sitokinlerin, tümör nekrotizan faktör alfanın epizodik nöbetlere yol açan glutamat reseptörlerinin aktivasyonu yoluyla nöronal hipereksitabiliteyi tetikleyebilen granülosit koloni uyarıc1 faktörü içeren COVID-19 ile ilişkili epilepsiyi açıklamak için çeşitli hipotezler öne sürülmüştür $(65,66)$. Öte yandan, bazı araştırmacılar nöbetlerin ensefalit ve virüsün beyne invazyonundan kaynaklanabileceğine inanmaktadır (67). Bununla birlikte, SARS$\mathrm{COV}-2$ virüsünün kan-beyin bariyerini (BBB) geçip geçemeyeceği hala tartışmalıdır $(27,68)$. Epilepsinin, bazı durumlarda lopinavir / ritonavir ve ribavirin gibi antiviral ilaçların advers ilaç reaksiyonu ile de ilişkili olabileceği belirtilmiştir (69).

Son olarak, ciddi COVID-19'lu hastalarda hipoksi, multiorgan yetmezliği ve metabolik ve elektrolit düzensizlikleri olabilir ve sofistike ilaç rejimleri ve terapötik müdahaleler gerektirebilir. Bu nedenle, bu hastalarda klinik veya subklinik akut semptomatik nöbetlerin ve status epileptikus beklenebilir. Ciddi COVID-19 olan hastalarda kognitif bozukluk da bildirilmiştir ancak bu durum ayrıntılı olarak incelenememiştir $(23,70)$.

\section{Guillain Barré Sendromu}

Guillain Barré sendromu (GBS) muhtemel bir enfeksiyon tarafindan tetiklenen ve periferik sisteme karşı immune reaksiyon sonucu gelişen bir otoimmun hastalıktır (71). Sendromdan önce genellikle periferik sinirleri ve spinal kökleri hedefleyen anormal bir immün yanıtı indükleyen enfeksiyon gözlenir. Mikrobiyal ve nöral antijenlerin arasındaki moleküler benzerlik bozukluğun gelişiminin arkasındaki 
en önemli neden olarak bildirilmiştir (72).

COVID -19 ve GBS birlikteliğine ilişkin pandemi başlangıcından beri çok sayıda vaka bildirimi bulunmaktadır (73-75). Zhao ve ark. kısa süre önce Wuhan'dan dönen, bir gün içinde ilerleyen alt ekstremitelerde bilateral akut kuvvetsizlik ve genel halsizlik yakınması ile başvuran 61 yaşında bir kadın hastada BOS analiz ve elektrofizyolojik çalışma ile GBS tanısı konduğunu bildirmişlerdir. Başvurunun sekizinci gününde öksürük ve ateş şikayetleri gelişen hastadan yapılan orofaringeal ters transkripsiyon polimeraz zincir reaksiyonu(RT-PCR) testinde SARS-coV-2 pozitif saptanmıştır. Hastanın SARS-CoV-2 salgınlarının meydana geldiği Wuhan'a seyahat geçmişi göz önüne alındığında, muhtemelen Wuhan'daki kalışı sırasında enfekte olduğu düşünülmüştür. Zamansal ilişki göz önüne alındığında, SARSCoV-2 enfeksiyonunun bu hastada GBS'ye sebep olabileceği düşünülmüştür. Ayrıca, bu hastada GBS semptomlarının başlangıcı SARS-CoV-2 enfeksiyonu periyodu ile çakışmıştır. Bu nedenle SARS-CoV-2 ile ilişkili GBS postenfeksiyözbir profil yerine parainfeksiyöz bir profil şeklini izleyebilir. Bununla birlikte başlangıçta ateş ve solunum semptomlarının olmaması nedeniyle hastada tesadüfen nedeni bilinmeyen GBS geliştiği ve SARS-CoV-2 enfeksiyonu nozokomiyal olarak edindiği alternatif açıklamada dikkate alınabilir (74).

Sadaghat ve arkadaşlarının vaka bildiriminde de 65 yaşında erkek hasta akut progresif simetrik asenden kuadriparezi semptomları ile başvurmuştur. Hastaneye yatmadan iki hafta önce hastanın öksürük, ateş ve dispne şikayetli olmuştur. COVID-19 için RT-PCR pozitiftir. EMG ile GBS teşhisi konulmuştur (34).

El otmani ve arkadaşlarının vaka bildiriminde 70 yaşında $7,5 \mathrm{mg}$ prednizolon alan romatoid artritli kadın hasta dört ekstremitede hızl ilerleyen, bilateral zayıflık ve karıncalanma ile başvurmuştur. Devam eden semptomların başlamasından üç gün önce, hasta 48 saat içinde kendiliğinden düzelen dispne ve ateş olmadan kuru öksürük atağı geçirmiştir. EMG ve BOS analizi ile teşhis konulmuştur. Devam eden semptomların başlamasından üç gün önce, hasta 48 saat içinde kendiliğinden düzelen dispne ve ateş olmadan kuru öksürük atağı geçirmiştir. EMG ve BOS analizi ile teşhis konulmuştur (el Otmani ). RT-PCR testinde SARS-CoV-2 orofaringealsürüntüde pozitif, BOS'ta negatif gelmiştir. BOS'tanegatif PCR analizi immün mekanizmayı desteklemektedir (76).

COVID-19, enflamatuar hücreleri uyarır ve çeşitli enflamatuar sitokinler üretir ve sonuç olarak bağışıklık aracılı süreçler oluşturur. GBS bir bağışıklık aracılı bozukluktur ve otoimmün bozukluğun bir mekanizması olarak moleküler benzerlik önemli bir rol oynar (74).

Çeşitli bakteriyel ve viral enfeksiyonlar sonucu tetiklenen postenfeksiyöz bir tablo olan GBS ile covid-19'un da benzer bir mekanizma ile ilişki olması muhtemel görülmekle birlikte etki mekanizması net olarak bilinmemektedir. GBS semptomları ve covid19'un solunumsal semptomlarının başlangıçlarının zamansal ilişkisi de göz önünde bulundurulmalıdır. GBS ve covid-19 birlikteliği ile ilişkili çok sayıda vaka bildirimi olmakla birlikte bu konuda daha fazla çalışmaya ihtiyaç vardır.

\section{COVID-19 Hastalarında Prognoz}

COVID-19 enfeksiyonuna yönelik birçok semptom ve bulgu birlikte görülebilmektedir. Olguların \%5'inde solunum yetmezliği, pnömoni, şok, çoklu organ yetmezliği ve çok ciddi olgularda; ARDS ve çoklu organ yetmezliğine sekonder ölüm gelişebilmektedir. COVID 19 hastalarında nörolojik bulgu ve bozuklukların ortaya çıkması prognozu negatif yönde etkilemektedir. İleri yaş, erkek cinsiyet, iskemik kalp hastalığ 1 , hipertansiyon, dibates mellitus (DM) ve kronik akciğer hastalıklarının kötü prognozda esas risk faktörleri olduğuna dair kanitlar mevcuttur $(78,79)$

Vital bulgular değerlendirildiğinde kötü prognozla seyreden hastalarda daha sık taşikardi ve/veya takipne bulunduğu ve bu hastaların oksijen satürasyonlarının \%93 ya da altında olduğu saptanmıştır. Bu bulgular prognozu kötü giden hastaların başvuru anında da klinik olarak kötü olduklarını düşündürmektedir. Klinisyenlerin bu vital bulgularla hastaların prognozu hakkında tahmin yürütebileceği düşünülmektedir (80).

Yüksek ateş, öksürük, halsizlik, iştahsızlık, miyalji ve diyare semptomlarının prognostik açıdan öngörücü olmadığı bildirilmiştir. Solunumsal, kardiyak ve nörolojik komplikasyonlar ile kötü prognoz arasında bir ilişki olduğu bildirilmiştir. Hızlı klinik kötüleşme inme gibi nörolojik bir olaya bağlı olabilmektedir ve bu da yüksek ölüm oranlarına neden olabilmektedir (81).

Beyin sapındaki solunum merkezinin virüsten etkilenmiş olmasının da, solunum yetmezliğine neden olabilen, bazı refleks mekanizmaları bozan ve hipoksiyi artırabilen bir neden olabileceği düşünülmektedir, bu nedenle de prognozu kötüleştireceği ön görülmüştür (82).

COVID-19 hastalığından iyileşen hastaların bir kısmında en az bir semptomun, özellikle de yorgunluk ve dispnenin devam ettiği bidirilmiştir (83).

\section{COVID 19 ve Psikiyatrik Bozukluklar}

COVID 19 tüm dünyayı derinden sarsan bir durumken kişilerin ruh sağlığını etkilemesi de beklenilen bir sonuçtur. Hastalığın medyada her gün işlenmesi, karantina ve sosyal izolasyon süreçleri, sevdiklerinden uzak kalma ve onları kaybetme korkusu, hatta kaybetmek; insanlarda tükenmişlik, kayg1, üzüntü, sinirlilik ve suçluluk hissi gibi pek çok olumsuz duygunun daha yoğun yaşanmasına yol açmıştır (84).

Karantina başı ıaşına bir travmadır ve akut stres bozukluğu ile kaygı bozuklukları riski erken dönemde artmıştır. Daha önceki yıllarda yapılan çalışmalar 1şığında uzun dönemde toplumda post travmatik stres bozukluğu, majör depresyon ve alkol, madde bağımlılı̆̆ vakalarının da artması beklenmektedir $(85,86)$. COVID-19'un ruh sağlığına etkisinin yanısıra, ruh hastalıklarının da COVID-19' a etkisini ve bu kısır döngüyü etkilediğini bir çok çalışma desteklemektedir. Örneğin; Çin'de yapılan bir çalışmada ruh sağlığı bozukluğu olan kişilerin enfeksiyona daha duyarlı olduğu vurgulanmıştır (87).

$\mathrm{Bu}$ duyarlılı̆̆ın artış nedenleri olarak bilişsel bozukluklar, risk farkındalığının azalması, hastalarda kişisel korunma ile ilgili gerekli önlemlerin alınamaması, psikiyatri servislerindeki sınırlı koşullar ve polikliniğe erişimdeki zorluklar gösterilmiştir. Ruh sağlı̆̆ bozuklukları olan kişiler, COVID-19 salgınının getirdiği duygusal tepkilerden daha fazla etkilenebilir ve bu da genel popülasyona kıyasla var olan bir bozukluğun nüksetmesine veya kötüleşmesine neden olabilir.

Ayrıca ruh sağlığı bozukluklarının pnömoni de dahil olmak üzere enfeksiyon riskini artırdığı bilinmektedir (88). COVID-19 salgınının 
aynı zamanda korku, kaygı ve depresyonun da yayıldığı bir salgın olduğunu söyleyebiliriz. Unutulmamalı ki salgın; toplumun tamamını asla eşit olarak etkilemez ve eşitsizlikler enfeksiyonların yayılmasını arttırır.

\section{Sonuç}

Yukarıda çok çeşitli yönlerden ele almaya çalıştı̆̆ımız COVID -19 pandemisi ve SARS-CoV-2 virüsünün neden olduğu bozukluklar ve hastalıklara ilişkin her gün yeni bir bilgi değişik uzmanlık alanlarınca bildirilmekte ve hastalığa ilişkin bilgilerimiz artmakta daha etkin önleme ve tedavi konularında tıp daha iyi bir konuma gelmektedir.

\section{Kaynaklar}

1.GBD 2016 Neurology Collaborators. Global, regional, and national burden of neurological disorders, 1990-2016: a systematic analysis for the Global Burden of Disease Study 2016. Lancet Neurol 2019; 18: 439-58.

2.Carroll WM. The global burden of neurological disorders. Lancet Neurol 2019;18(5):418-419.

3.Sellner J, Taba P, Öztürk S, Helbok R. The need for neurologists in the care of COVID-19 patients. Eur J Neurol. 2020 Apr 23:10.1111/ene.14257.

4.Román GC, Spencer PS, Reis J, Buguet A, Faris MEA, Katrak SM, et al. WFN Environmental Neurology Specialty Group. The neurology of COVID-19 revisited: A proposal from the Environmental Neurology Specialty Group of the World Federation of Neurology to implement international neurological registries. J Neurol Sci. 2020 May 7;414:116884.

\section{5.Öztürk Ş. COVID-19 ve Nöroloji. Turk J Neurol 2020;26:109-111}

6.Román GC, Reis J, Spencer PS, Buguet A, Öztürk S, Wasay M; World Federation of Neurology Environmental Neurology Specialty Group. COVID-19 internationa neurological registries. Lancet Neurol. 2020 Jun;19(6):484-485. doi: 10.1016/S14744422(20)30148-4. Epub 2020 May 26. PMID: 32470417; PMCID: PMC7250559.

7.Moro E, Priori A, Beghi E, Helbok R, Campiglio L, Bassetti CL, et al. EAN core COVID-19 Task Force. The international EAN survey on neurological symptoms in patients with COVID-19 infection. Eur J Neurol. 2020 Jun 17:10.1111

8.Chen N, Zhou M, Dong X, et al. Epidemiological and clinical characteristics of 99 cases of 2019 novel coronavirus pneumonia in Wuhan, China: a descriptive study. Lancet 2020;395:507-13.

9.Huang C, Wang Y, Li X, et al. Clinical features of patients infected with 2019 novel coronavirus in Wuhan, China. The Lancet 2020; 395(10223): 497-506.

10.Wang D, Hu B, Hu C, Zhu F, Liu X, Zhang J, et al. Clinical Characteristics of 138 Hospitalized Patients With 2019 Novel Coronavirus-Infected Pneumonia in Wuhan, China. JAMA 2020; Mar 17;323(11):1061-1069.

11.Behzad S, Aghaghazvini L, Radmard AR, Gholamrezanezhad A. Extrapulmonary manifestations of COVID-19: Radiologic and clinical overview. Clin Imaging. 2020 Oct;66:35-41.

12.Wu F, Zhao S, Yu B, et al. A new coronavirus associated with human respiratory disease in China [published correction appears in Nature. 2020 Apr;580(7803):E7] Nature. 2020;579(7798):265-269. doi:10.1038/s41586-020-2008-3).

13.https://www.who.int/emergencies/diseases/novel-coronavirus-2019/technicalguidance/naming-the-coronavirus-disease-(covid-2019)-and-the-virus-that-causes-it. Accessed 1 Temmuz 2020.)

14.Liu Z, Xiao X, Wei X, et al. Composition and divergence of coronavirus spike proteins and host ACE2 receptors predict potential intermediate hosts of SARS-CoV-2. J Med Virol. 2020;92(6):595-601.

15.Lu R, Zhao X, Li J, et al. Genomic characterisation and epidemiology of 2019 novel coronavirus: implications for virus origins and receptor binding. Lancet. 2020;395(10224):565-574.

16.Chowell G, Abdirizak F, Lee S, et al. Transmission characteristics of MERS and SARS in the healthcare setting: a comparative study. BMC Med. 2015;13:210. Published 2015 Sep 3. doi:10.1186/s12916-015-0450-0

17.Türkiye Bilimler Akademisi Covid 19 Pandemi Değerlendirme Raporu . http://www. tuba.gov.tr/files/images/2020/kovidraporu/Covid-19\%20Raporu-Final+.pdf Accessed: Ağustos 2020)

18.Acar T, Acıman Demirel E, Afşar N, Akçalı A, Akman Demir G, Alagöz AN, et al. Nörolojik bakış açısından COVID 19. Turk J Neurol 2020;26:56-106

19.https://covid19.who.int/?gclid=EAIaIQobChMIyrOW5pb_6gIVDO7tCh29-AO_ EAAYASAAEgJJpfD_BwE Accessed: 1 Ağustos 2020)

20.www.who.int Coronavirus Disease (COVID-19) Dashboard/WHO Coronavirus disease (COVID-19) Dashboard. Accessed 25 Eylül 2020

21.Wiersinga WJ, Rhodes A, Cheng AC, Peacock SJ, Prescott HC. Pathophysiology, Transmission, Diagnosis, and Treatment of Coronavirus Disease 2019 (COVID-19): A Review. JAMA. 2020;10.1001/jama.2020.12839.

22.Zhai P, Ding Y, Wu X, Long J, Zhong Y, Li Y. The epidemiology, diagnosis and treatment of COVID-19. Int J Antimicrob Agents. 2020;55(5):105955.

23.Mao L, Jin H, Wang M, et al. Neurologic Manifestations of Hospitalized Patients With Coronavirus Disease 2019 in Wuhan, China [published online ahead of print, $2020 \mathrm{Apr}$ 10]. JAMA Neurol. 2020;77(6):1-9.

24.Cunha P, Herlin B, Vassilev K, et al. Movement disorders as a new neurological clinical picture in severe SARS-CoV-2 infection [published online ahead of print, 2020 Aug 12]. Eur J Neurol. 2020;10.1111/ene.14474.

25.Kirschenbaum D, Imbach LL, Ulrich S, et al. Inflammatory olfactory neuropathy in two patients with COVID-19. Lancet. 2020;396(10245):166.

26.Desforges M, Le Coupanec A, Dubeau P, et al. Human Coronaviruses and Other Respiratory Viruses: Underestimated Opportunistic Pathogens of the Central Nervous System?. Viruses. 2019;12(1):14.

27.Wu Y, Xu X, Chen $\mathrm{Z}$, et al. Nervous system involvement after infection with COVID-19 and other coronaviruses. Brain Behav Immun. 2020;87:18-22.

28.Montalvan V, Lee J, Bueso T, De Toledo J, Rivas K. Neurological manifestations of COVID-19 and other coronavirus infections: A systematic review. Clin Neurol Neurosurg $2020 ; 194,105921$.

29.Abboud H, Abboud FZ, Kharbouch H, Arkha Y, El Abbadi N, El Ouahabi A. COVID-19 and SARS-Cov-2 Infection: Pathophysiology and Clinical Effects on the Nervous System. World Neurosurg. 2020 Aug;140:49-53.

30.Karadaş Ö, Öztürk B, Sonkaya AR. A prospective clinical study of detailed neurological manifestations in patients with COVID-19. Neurol Sci. 2020 Aug;41(8):1991-1995.

31.Giorgianni A, Vinacci G, Agosti E, Cariddi LP, Mauri M, Baruzzi F, et al. Transient acute-onset tetraparesis in a COVID-19 patient. Spinal Cord. 2020 Sep;58(9):1042-1044.

32.Baig AM, Khaleeq A, Ali U, Syeda H. Evidence of the COVID-19 virus targeting the CNS: tissue distribution, host-virus interaction, and proposed neurotropic mechanisms. ACS Chem Neurosci. 2020;11:995-8.

33.Zhao K, Huang J, Dai D, Feng Y, Liu L, Nie S. Acute myelitis after SARS-CoV-2 infection: a case report. Medrivx. 2020. 10.1101/2020.03.16.20035105.

34.Sedaghat AR, Gengler I, Speth MM. Olfactory Dysfunction: A Highly Prevalent Symptom of COVID-19 With Public Health Significance. Otolaryngol Head Neck Surg. $2020 \mathrm{Jul} ; 163(1): 12-15$

35.Hopkins C, Surda P, Kumar N. Presentation of new onset anosmia during the COVID-19 pandemic. Rhinology. 2020;58(3):295-298.

36. Moein ST, Hashemian SM, Mansourafshar B, Khorram-Tousi A, Tabarsi P, Doty RL. Smell dysfunction: a biomarker for COVID-19. Int Forum Allergy Rhinol. 2020;10(8):944-950.

37.Torabi A, Mohammadbagheri E, Akbari Dilmaghani N, Bayat AH, Fathi M, Vakili K et al. Proinflammatory Cytokines in the Olfactory Mucosa Result in COVID-19 Induced Anosmia. ACS Chem Neurosci. 2020 Jul 1;11(13):1909-1913.

Covid-19 ve Nöroloji - Ișık ve ark. 
38.Dalakas MC. Guillain-Barré syndrome: The first documented COVID-19-triggered autoimmune neurologic disease: More to come with myositis in the offing. Neurol Neuroimmunol Neuroinflamm. 2020;7(5):e781.

39.Markus HS, Brainin M. COVID-19 and stroke-A global World Stroke Organization perspective. Int J Stroke. 2020;15(4):361-364

40.Hess DC, Eldahshan W, Rutkowski E. COVID-19-Related Stroke. Transl Stroke Res. 2020;11(3):322-325

41.Porfidia A, Pola R. Venous thromboembolism in COVID-19 patients. J Thromb Haemost. 2020 Jun;18(6):1516-1517.

\section{Ma RCW, Holt RIG. COVID-19 and diabetes. Diabet Med. 2020;37(5):723-725.}

43.Dafer RM, Osteraas ND, Biller J. Acute Stroke Care in the Coronavirus Disease 2019 Pandemic. J Stroke Cerebrovasc Dis. 2020;29(7):104881.

44.Zhang L, Yan X, Fan Q, Liu H, Liu X, Liu Z, Zhang Z. D-dimer levels on admission to predict in-hospital mortality in patients with Covid-19. J Thromb Haemost. 2020 Jun;18(6):1324-1329.

45.Topçuoğlu MA, Arsava EM, Özdemir AÖ. COVID-19 pandemisinde akut iskemil inme tedavisi: Uzman görüşü.Türk Beyin Damar Hastalıkları Dergisi 2020; 26(1): 91-94 Turkish Journal of Cerebrovascular Diseases 2020; 26(1): 91-94

46.Ellul M, Solomon T. Acute encephalitis - diagnosis and management. Clin Med (Lond). 2018;18(2):155-159. doi:10.7861/clinmedicine.18-2-155

47.Granerod J, Ambrose HE, Davies NW, Clewley JP, Walsh AL, Morgan D, et al. UK Health Protection Agency (HPA) Aetiology of Encephalitis Study Group. Causes of encephalitis and differences in their clinical presentations in England: a multicentre, population-based prospective study. Lancet Infect Dis. 2010 Dec;10(12):835-44.

48.Kumar R: Encephalitis \& Encephalopathies in Medical Emergencies in Children. Ed Singh M,. Sagar Publications 2018. New Delhi. 2012; 324-32.

49.Montalvan V, Lee J, Bueso T, De Toledo J, Rivas K. Neurological manifestations of COVID-19 and other coronavirus infections: A systematic review. Clin Neurol Neurosurg. 2020;194:105921.

50.Carod-Artal FJ. Neurological complications of coronavirus and COVID-19. Rev Neurol. 2020;70(9):311-322.

51.Lau KK, Yu WC, Chu CM, Lau ST, Sheng B, Yuen KY. Possible central nervous system infection by SARS coronavirus. Emerg Infect Dis. 2004;10(2):342-344.

52.Huang YH, Jiang D, Huang JT. SARS-CoV-2 Detected in Cerebrospinal Fluid by PCR in a Case of COVID-19 Encephalitis. Brain Behav Immun. 2020 Jul;87:149

53.Asadi-Pooya AA, Simani L. Central nervous system manifestations of COVID-19: A systematic review. J of Neurological Sci. 2020;413:116832.

54.Paterson RW, Brown RL, Benjamin L, Nortley R, Wiethoff S, Bharucha T, et al; UCL Queen Square National Hospital for Neurology and Neurosurgery COVID-19 Study Group. The emerging spectrum of COVID-19 neurology: clinical, radiological and laboratory findings. Brain. 2020 Jul 8:awaa240.

55.Munz M, Wessendorf S, Koretsis G, Tewald F, Baegi R, Krämer S, Geissler M, Reinhard M. Acute transverse myelitis after COVID-19 pneumonia. J Neurol. 2020 Aug;267(8):2196-2197.

56.Delorme C, Paccoud O, Kas A, Hesters A, Bombois S, Shambrook P. et al. (2020), Covid-19-related encephalopathy: a case series with brain FDG-PET/CT findings. Eur J Neurol 2020 Aug 15:10.1111/ene.14478

57.Koyuncu OO, Hogue IB, Enquist LW. Virus infections in the nervous system. Cell Host Microbe. 2013;13(4):379-393.

58.Moriguchi T, Harii N, Goto J, et al. A first case of meningitis/encephalitis associated with SARS-Coronavirus-2. Int J Infect Dis. 2020;94:55-58.

59.Efe IE, Aydin OU, Alabulut A, Celik O, Aydin K. COVID-19-Associated Encephalitis Mimicking Glial Tumor. World Neurosurg. 2020;140:46-48.

60.von Weyhern CH, Kaufmann I, Neff F, Kremer M. Early evidence of pronounced brain involvement in fatal COVID-19 outcomes. Lancet. 2020;395(10241):e109.
61.Robinson CP, Busl KM. Meningitis and encephalitis management in the ICU. Curr Opin Crit Care 2019;25(5):423-429

62.Yasri S, Wiwanikit V. COVID-19 and Epilepsy. Ann Indian Acad Neurol. 2020;23(Suppl 1):S43.

63.Karimi N, SharifiRazavi A (2020) Rouhani NJIRCMJ. Frequent convulsive seizures in an adult patient with COVID-19: a case report. Iran Red Crescent Med J (InPress). https:// doi.org/10.5812/ircmj.102828

64.Lu L, Xiong W, Liu D, et al. New onset acute symptomatic seizure and risk factors in coronavirus disease 2019: A retrospective multicenter study. Epilepsia. 2020;61(6):e49-e53.

65.Libbey JE, Fujinami RS. Neurotropic viral infections leading to epilepsy: focus on Theiler's murine encephalomyelitis virus. Future Virol. 2011;6(11):1339-1350.

66.Singhi P. Infectious causes of seizures and epilepsy in the developing world. Dev Med Child Neurol. 2011;53(7):600-609.

67.Moriguchi T, Harii N, Goto J, Harada D, Sugawara H, Takamino J, et al. A first case of meningitis/encephalitis associated with SARS-Coronavirus-2. Int J Infect Dis. 2020 May;94:55-58.

68.Filatov A, Sharma P, Hindi F, Espinosa PS. Neurological Complications of Coronavirus Disease (COVID-19): Encephalopathy. Cureus. 2020 Mar 21;12(3):e7352.

69.Ying W, Qian Y, Kun Z. Drugs supply and pharmaceutical care management practices at a designated hospital during the COVID-19 epidemic. Res Social Adm Pharm. 2020 Apr 6:S1551-7411(20)30325-9.

70.Chen N, Zhou M, Dong X, et al. Epidemiological and clinical characteristics of 99 cases of 2019 novel coronavirus pneumonia in Wuhan, China: a descriptive study. Lancet. 2020;395(10223):507-513

71.Malek E, Salameh J. Guillain-Barre Syndrome. Semin Neurol 2019 Oct;39(5):589595.7

72.Willison HJ, Jacobs BC, van Doorn PA. Guillain-Barré syndrome. Lancet. 2016 Aug $13 ; 388(10045): 717-27$

73.Velayos Galán A, Del Saz Saucedo P, Peinado Postigo F, Botia Paniagua E. Guillain-Barré syndrome associated with SARS-CoV-2 infection. Neurologia. 2020 May;35(4):268-269.

74.Zhao H, Shen D, Zhou H, Liu J, Chen S. Guillain-Barré syndrome associated with SARS-CoV-2 infection: causality or coincidence? Lancet Neurol. 2020 May;19(5):383384

75.Camdessanche JP, Morel J, Pozzetto B, Paul S, Tholance Y, Botelho-Nevers E. COVID-19 may induce Guillain-Barré syndrome. Rev Neurol (Paris). 2020 Jun;176(6):516-518.

76.El Otmani H, El Moutawakil B, Rafai MA, El Benna N, El Kettani C, Soussi M, El Mdaghri N, Barrou H, Afif H. Covid-19 and Guillain-Barré syndrome: More than a coincidence! Rev Neurol (Paris). 2020 Jun;176(6):518-519.

77.Wu Z, McGoogan JM. Characteristics of and Important Lessons From the Coronavirüs Disease 2019 (COVID-19) Outbreak in China: Summary of a Report of 72314 Cases From the Chinese Center for Disease Control and Prevention. JAMA 2020:1239-1242.

78.Jiang F, Deng L, Zhang L, Cai Y, Cheung CW, Xia Z. Review of the Clinical Characteristics of Coronavirüs Disease 2019 (COVID-19). J Gen Intern Med 2020;35:1545-1549.

79.Chen $\mathrm{T}, \mathrm{Wu} \mathrm{D}$, Chen $\mathrm{H}$, et al. Clinical characteristics of 113 deceased patients with coronavirüs disease 2019: retrospective study. BMJ 2020;368:m1091

80.Jiang F, Deng L, Zhang L, Cai Y, Cheung CW, Xia Z. Review of the Clinica Characteristics of Coronavirüs Disease 2019 (COVID-19). J Gen Intern Med 2020;35:1545-1549

81.Jin H, Hong C, Chen S, Zhou Y, Wang Y, Mao L, Li Y, He Q, Li M, Su Y, Wang D, Wang L, Hu B. Consensus for prevention and management of coronavirus disease 2019 (COVID-19) for neurologists. Stroke Vasc Neurol. 2020 Jun;5(2):146-151.

82.Wu Z, McGoogan JM. Characteristics of and Important Lessons From the Coronavirüs 
Disease 2019 (COVID-19) Outbreak in China: Summary of a Report of 72314 Cases From the Chinese Center for Disease Control and Prevention. JAMA 2020:1239-1242).

83.Carfì A, Bernabei R, Landi F; Gemelli Against COVID-19 Post-Acute Care Study Group. Persistent Symptoms in Patients After Acute COVID-19 [published online ahead of print, 2020 Jul 9]. JAMA. 2020;324(6):603-605. doi:10.1001/jama.2020.12603).

84.Brooks SK, Webster RK, Smith LE, et al. The psychological impact of quarantine and how to reduce it: rapid review of the evidence. Lancet 2020;395(10227):912-920.

85.Wu P, Liu X, Fang Y, et al. Alcohol abuse/dependence symptoms among hospital employees exposed to a SARS outbreak. Alcohol Alcohol. 2008;43(6):706-712.

86.Sprang G, Silman M. Posttraumatic stress disorder in parents and youth after healthrelated disasters. Disaster Medicine \& Public Health Preparedness 2013; 7(1): $105-10$

87.Yao H, Chen JH, Xu YF. Patients with mental health disorders in the COVID-19 epidemic. Lancet Psychiatry. 2020;7(4):e21.

88. Seminog OO, Goldacre MJ. Risk of pneumonia and pneumococcal disease in people with severe mental illness: English record linkage studies. Thorax. 2013;68(2):171-176. 